\title{
Penerapan Model Pembelajaran Numbered Heads Together dengan Media Flashcard dalam Peningkatan Pembelajaran IPS tentang Jenis Pekerjaan pada Siswa Kelas III SD Negeri 1 Bumirejo Tahun Ajaran 2017/2018
}

\author{
Lilis Muryani ${ }^{1}$, Imam Suyanto ${ }^{2}$, Ratna Hidayah ${ }^{3}$ \\ 1,2,3 Universitas Sebelas Maret \\ hanazawaherozui16@gmail.com
}

\section{Article History}

accepted 01/06/2019

\begin{abstract}
The objectives of this research is to describe the steps on the use of scientific approach using graphics media to improve learning outcomes of social science about type of work. This research is a collaborative Classroom Action Research (CAR) conducted within three cycles. Subjects of this research were third-grade student. The data were collected from the teacher and fifth-grade students. Validity of data in this research was analyzed using triangulation of sources and triangulation of technique. Data analysis techniques used in this research are data reduction, data display, and drawing conclusion. The result of this research is Numbered Heads Together using Flashcard improve learning the cycle I completeness $78 \%$, the cycle II completeness $85 \%$, the cycle III completeness $86 \%$. The conclusion of this research is the use of numbered heads together learning model using flashcard media can improve learning outcomes of social science about type of work for the third-grade students of SD Negeri 1 Bumirejo in the academic year of 2017/2018.
\end{abstract}

Keywords: Numbered Heads Together, Flashcard media, improve social science learning

\section{Abstrak}

Tujuan penelitian ini yaitu meningkatkan pembelajaran IPS tentang jenis pekerjaan. Penelitian ini merupakan penelitian tindakan kelas (PTK) kolaboratif melalui tiga siklus dengan subjek penelitian siswa kelas III. Sumber data penelitian ini adalah guru dan siswa. Validitas data menggunakan triangulasi sumber dan triangulasi teknik. Teknik analisis data pada penelitian ini yaitu reduksi data, penyajian data dan penarikan kesimpulan. Hasil penelitian menunjukkan bahwa model Numbered Heads Together dengan media Flashcard mampu meningkatkan pembelajaran yaitu pada siklus I ketuntasannya $78 \%$, siklus II ketuntasannya $85 \%$, siklus III ketuntasannya $86 \%$. Simpulan dari penelitian ini adalah penerapan model pembelajaran Numbered Heads Together dengan media Flashcard dapat meningkatkan pembelajaran IPS tentang jenis pekerjaan.

Kata Kunci: Numbered Heads Together, media Flashcard, pembelajaran IPS 


\section{PENDAHULUAN}

Pendidikan nasional berfungsi untuk mengembangkan kemampuan dan membentuk watak serta peradaban bangsa yang bermanfaat dalam rangka mencerdaskan kehidupan bangsa, dan bertujuan untuk berkembangnya potensi peserta didik agar menjadi manusia yang beriman dan bertaqwa kepada Tuhan Yang Maha Esa (Undang-Undang Sistem Pendidikan Nasional Nomor 20 Tahun 2003).

Usaha dalam mencapai tujuan Pendidikan Nasional tersebut, diperlukan adanya suatu kerja sama dan dukungan dari berbagai pihak baik dari pemerintah, sekolah, keluarga maupun lingkungan masyarakat sekitar. Guru harus mampu mewujudkan suasana belajar dan proses pembelajaran yang mampu mengembangkan potensi diri dari peserta didik. Selain itu, guru juga harus menggunakan pendekatan dan media yang membuat pembelajaran menjadi lebih bermakna agar dapat meningkatkan pembelajaran siswa.

Pendapat diatas juga didukung oleh pendapat Nasution (Susanto, 2012 :23) yang menyatakan bahwa mengajar adalah aktivitas guru dalam mengatur dan mengorganisasikan lingkungan dan menghubungkannya dengan anak agar terjadi proses belajar. Undang-Undang Nomor 20 Tahun 2003 tentang Sisdiknas ber pendapat bahwa "pembelajaran diartikan sebagai proses interaksi peserta didik dengan pendidik dan sumber belajar pada suatu lingkungan belajar".

IPS merupakan suatu kajian terpadu dari ilmu-ilmu kemanusiaan dan ilmu-ilmu sosial yang meramu disiplin-disiplin sosial, seperti antropologi, arkeologi, ekonomi, geografi, sejarah, hukum, ilmu politik, agama, dan sosiologi guna meningkatkan kemampuan kewarganegaraan (Susanto, 2013 :143-144). Tujuan utama pembelajaran IPS adalah untuk membentuk mental yang baik terhadap segala perubahan yang terjadi dan mengembangkan kepekaan siswa pada masalah sosial serta mampu mengatasi masalah tersebut di lingkungannya. Hal tersebut menunjukkan bahwa IPS merupakan mata pelajaran yang harus dikuasai siswa agar ia mampu menerapkannya dalam kehidupan sehari-hari. Pembelajaran IPS jika dilaksanakan menggunakan pendekatan yang tepat tentunya akan menghasilkan pembelajaran yang bermakna.

Berdasarkan hasil observasi dan wawancara yang dilakukan terhadap guru kelas III SD Negeri 1 Bumirejo pada hari Senin, 6 November 2017 diperoleh keterangan bahwa aktivitas belajar siswa rendah. Namun keberanian siswa dalam mengajukan pertanyaan dan pendapat masih kurang. Hasil analisis nilai UTS I tahun ajaran 2017/2018 menunjukkan bahwa tingkat rata-rata kelas belum mencapai Kriteria Ketuntasan Minimal. KKM yang ditetapkan untuk mata pelajaran IPS=75.

Lebih lanjut lagi, menurut hasil wawancara terhadap guru kelas III SD Negeri 1 Bumirejo mengenai pembelajaran IPS tentang jenis pekerjaan, menunjukkan bahwa perlu adanya motivasi belajar agar siswa dapat benar-benar memahami materi pembelajaran yang disampaikan oleh guru. Guru kelas III SD Negeri 1 Bumirejo juga menambahkan bahwa siswa sering mengalami kesulitan dalam menerima pembelajaran IPS.

Berdasarkan kenyataan di atas, peneliti melakukan penelitian tindakan kelas yang melibatkan semua siswa, sehingga mengaktifkan siswa dan mampu membangkitkan motivasi belajar siswa. Salah satunya melalui model pembelajaran Numbered Heads Together dengan media Flashcard.

Langkah-langkah penerapan model pembelajaran NHT menurut Shoimin (2014: 108), sebagai berikut: (1) siswa dibagi dalam kelompok. Serta setiap siswa dalam setiap kelompok mendapat nomor; (2) guru memberikan tugas dan masing-masing kelompok mengerjakannya; (3) kelompok mendiskusikan jawaban yang benar dan memastikan tiap anggota kelompok dapat mengetahui jawabannya dengan benar; (4) guru memanggil salah satu nomor siswa dan nomor yang dipanggil keluar dari kelompoknya melaporkan atau menjelaskan hasil kerja sama mereka; (5) tanggapan dengan teman lain, kemudian guru menunjuk nomor yang lain; (6) kesimpulan. 
Flashcard adalah media pembelajaran dalam bentuk kartu bergambar seukuran postcard atau sekitar 25 × $30 \mathrm{~cm}$ (Susilana 2007: 93). Melalui media ini siswa akan lebih tertarik dalam belajar karena media yang disajikan tidak hanya gambar dari buku sumber. Dengan adanya ketertarikan siswa dalam belajar, diharapkan dapat menanamkan materi lebih dalam dari diri siswa yang nantinya dapat meningkatkan proses dan hasil belajar pada siswa.

Berdasarkan pemaparan mengenai model pembelajaran Numbered Heads Together dengan media Flashcard, dapat disimpulkan bahwa penerapan pembelajaran NHT yang merupakan varian dari belajar kelompok dengan alat bantu pembelajaran dengan media flashcard yang dilaksanakan dengan langkah-langkah pembelajaran, meliputi: (a) Guru membagi kelas menjadi beberapa kelompok-kelompok kecil. Setiap anggota kelompok mendapatkan sebuah nomor dengan media Flashcard. (b) Guru memberikan tugas berupa kumpulan pertanyaan yang harus dijawab oleh tiap-tiap kelompok dengan media Flashcard. (c) Tiap kelompok memikirkan jawaban atas pertanyaan guru dengan menggunakan media Flashcard. Serta memastikan tiap anggota kelompok mengetahui jawabannya dengan benar. (d) Guru memanggil nomor siswa dan nomor yang dipanggil keluar dari kelompoknya melaporkan atau menjelaskan hasil kerja sama mereka. (e) Guru mengembangkan diskusi lebih mendalam, sehingga peserta didik dapat menemukan jawaban pertanyaan sebagai pengetahuan yang utuh. (f) Kesimpulan.

Rumusan masalah dalam penelitian ini yaitu apakah penerapan model pembelajaran Numbered Heads Together dengan media Flashcard dapat meningkatkan pembelajaran IPS tentang jenis pekerjaan?

Penelitian ini bertujuan untuk meningkatkan pembelajaran IPS tentang jenis pekerjaan.

\section{METODE}

Penelitian ini dilaksanakan di kelas III SD Negeri 1 Bumirejo, Kecamatan Kebumen, Kabupaten Kebumen. Subjek penelitian ini adalah 26 siswa yang terdiri dari 14 siswa laki-laki dan 12 siswa perempuan. Penelitian ini dilaksanakan mulai bulan November 2017 sampai dengan bulan Mei 2018.

Alat pengumpulan data dalam penelitian ini yaitu instrumen tes yang berupa lembar evaluasi dan instrumen nontes yang berupa lembar observasi dan pedoman wawancara. Penelitian ini merupakan penelitian tindakan kelas kolaboratif antara peneliti sebagai perencana dan guru kelas III sebagai pelaksana tindakan. Observer pada penelitian ini adalah 2 orang teman sejawat dan peneliti sendiri. Data dari hasil penelitian berupa hasil observasi terhadap penerapan model pembelajaran Numbered Heads Together dengan media Flashcard oleh guru, respon siswa terhadap pembelajaran yang menerapkan model, dan hasil evaluasi siswa. Uji validitas data menggunakan triangulasi yang merupakan penggabungan dari berbagai sumber data dan teknik pengumpulan data yang telah ada (Sugiyono, 2016: 241). Penelitian ini menggunkan triangulasi sumber dan teknik. Data tersebut kemudian dianalisis dengan tiga tahapan: (1) reduksi data, (2) penyajian data, (3) penarikan kesimpulan.

Indikator kinerja penelitian baik dari segi proses oleh guru dan siswa maupun hasil pelaksanaan pembelajaran melalui penerapan model pembelajaran Numbered Heads Together dengan media Flashcard sebesar 85\%. KKM hasil belajar yang ditargetkan pada penelitian ini yaitu 75 .

Penelitian dilaksanakan selama 3 siklus. Setiap siklus terdiri dari 2 pertemuan dengan 4 tahapan sesuai pendapat Arikunto (2013: 131) yaitu (1) perencanaan, (2) pelaksanaan, (3) pengamatan, dan (4) refleksi.

Pada pelaksanaannya, tahapan ini selalu berhubungan dan berkelanjutan dalam prosesnya, serta mengalami perbaikan-perbaikan sesuai dengan hasil observasi dan refleksi hingga memenuhi hasil atau tujuan yang diharapkan. 
HASIL DAN PEMBAHASAN

Data hasil observasi dari 3 observer terkait model pembelajaran Numbered Heads Together dengan media Flashcard sebagai berikut.

Tabel 1. Hasil Observasi terhadap Guru dan Siswa

\begin{tabular}{clcc}
\hline Siklus & Pembanding & Guru & Siswa \\
\hline \multirow{2}{*}{ I } & Rata-rata & 3,0 & 3,2 \\
\cline { 2 - 4 } & Persentase & 75,9 & 79,9 \\
\hline \multirow{2}{*}{ II } & Rata-rata & 3,4 & 3,6 \\
\cline { 2 - 4 } & Persentase & 85,5 & 89,9 \\
\hline \multirow{2}{*}{ III } & Rata-rata & 3,8 & 3,8 \\
\cline { 2 - 4 } & Persentase & 93,8 & 95,4 \\
\hline
\end{tabular}

Berdasarkan tabel di atas, dapat diketahui bahwa hasil observasi penerapan model pembelajaran Numbered Heads Together dengan media Flashcard oleh guru dan siswa mengalami peningkatan dari siklus I sampai siklus III. Persentase guru dan siswa pada siklus II dan III telah menunjukkan bahwa indikator kinerja yang ditargetkan telah tercapai yaitu $85 \%$.

Berdasarkan hasil wawancara, guru mengakui bahwa belum melaksanakan pembelajaran dengan maksmimal. Pembelajaran pada siklus I dilaksanakan melalui 2 pertemuan dengan indikator menyebutkan menjelaskan jenis pekerjaan, mengenal jenis-jenis pekerjaan yang ada di lingkungan sekitar rumah, menyebutkan jenis pekerjaan yang menghasilkan barang dan menyebutkan jenis pekerjaan yang menghasilkan jasa. Pelaksanaan pada siklus I secara keseluruhan telah sesuai dengan skenario yang direncanakan, namun persentase rata-rata yang diperoleh guru dan siswa pada siklus I belum mencapai indikator yakni 75,9\% dan 79,9\%. Terdapat beberapa kendala yang harus dibenahi, sehingga penelitian dilanjutkan ke siklus II.

Pembelajaran pada siklus II dilaksanakan bedasarkan hasil refleksi siklus I dengan indikator mengidentifikasi alasan orang harus bekerja, menjelaskan pengertian semangat kerja dan menyebutkan ciri-ciri semangat kerja. Hasil penelitian pada siklus II menunjukkan bahwa adanya peningkatan persentase rata-rata guru dan siswa menjadi $85,5 \%$ dan $89,9 \%$.

Pembelajaran pada siklus III dilaksanakan bedasarkan hasil refleksi siklus II dengan indikator menyebutkan contoh perilaku semangat kerja, menyebutkan manfaat semangat kerja dan menyebutkan akibat tidak memiliki semangat kerja. Hasil penelitian pada siklus III menunjukkan bahwa adanya peningkatan persentase ratarata guru dan siswa menjadi $93,8 \%$ dan $95,4 \%$. Secara keseluruhan pembelajaran yang dilakukan telah sesuai dengan skenario yang direncanakan dan kendala yang ada tidak terlalu berpengaruh negatif bagi langkah pembelajaran yang telah tersusun diskenario, sehingga peneliti mencukupkan tindakan karena persentase tersebut telah menunjukkan tercapainya indikator yang ditargetkan yaitu $85 \%$.

Peningkatan pembelajaran IPS tentang jenis pekerjaan pada siswa kelas III SD Negeri 1 Bumirejo meliputi peningkatan proses dan hasil. Peningkatan proses telah dijelaskan sebelumnya pada langkah-langkah penerapan model pembelajaran Numbered Heads Together dengan media Flashcard baik dari segi guru maupun siswa. Berikut pemaparan mengenai peningkatan pembelajaran pada siklus I, II, dan III jika ditinjau dari segi hasil. 
Tabel 2. Peningkatan Hasil Pembelajaran Antarsiklus

\begin{tabular}{ccc}
\hline \multirow{2}{*}{$\begin{array}{c}\text { Siklu } \\
\text { s }\end{array}$} & \multicolumn{2}{c}{ Ketuntasan } \\
\cline { 2 - 3 } & $\begin{array}{c}\text { Tuntas } \\
(\%)\end{array}$ & $\begin{array}{c}\text { Belum } \\
\text { Tuntas (\%) }\end{array}$ \\
\hline I & 78 & 22 \\
II & 85 & 15 \\
III & 86 & 14 \\
\hline
\end{tabular}

Berdasarkan tabel di atas, dapat dilihat bahwa pada siklus I persentase ratarata ketuntasana siswa $78 \%$. Persentase itu belum menunjukkan tercapainya indikator yang ditargetkan, sehingga penelitian dilanjutkan ke siklus II. Pada siklus II persentase rata-rata ketuntasan siswa naik menjadi $85 \%$. Pada siklus II, persentase ketuntasan hasil belajar siswa juga belum menunjukkan tercapainya indikator yang telah ditargetkan, sehingga penelitian dilanjutkan kembali ke siklus III. Pada siklus III persentase rata-rata ketuntasan siswa meningkat kembali menjadi $86 \%$. Pada siklus III, indikator kinerja penelitian yang ditargetkan telah tercapai, sehingga penelitian dihentikan.

Kendala atau hambatan yang muncul antara lain: guru belum melaksanakan salah satu langkah pembelajaran menggunakan model Numbered Heads Together dengan media Flashcard. Solusi yang ditempuh antara lain; mengkoordinasi guru agar melaksanakan langkah model Numbered Heads Together dengan media Flashcard.

Hasil penelitian ini sependapat dengan Pratiwi, Ulva (2015) yang mengemukakan bahwa melalui penerapan model pembelajaran Numbered Heads Together dengan media Flashcard dapat meningkatkan pembelajaran. Pendapat yang dikemukakan oleh Miaz (2015), bahwa penerapan model pembelajaran Numbered Heads Together dengan media Flashcard mampu meningkatkan hasil.

\section{SIMPULAN}

Berdasarkan analisis pelaksanaan penelitian, hasil penelitian dan pembahasan maka dapat disimpulkan bahwa penerapan model pembelajaran Numbered Heads Together dengan media Flashcard dapat meningkatkan pembelajaran IPS tentang jenis pekerjaan.

\section{DAFTAR PUSTAKA}

Arikunto, S. (2013). Prosedur Penelitian Suatu Pendekatan Praktik. Jakarta: Rineka Cipta.

Miaz, Y. (2015). The Implementation Of Numbered Heads Together To Improve The Students' Achievement Of Social Sciences In Primary School. Journal of Social Sciences, 8 (10): 44. Diperoleh 20 Mei 2018, dari http://www.aensiweb.net/AE NSIWEB/rjss/rjss/2015/Nove mber\%20December/4045.pdf

Shoimin, A. (2016). 68 Model Pembelajaran Inovatif dalam Kurikulum 2013. Yogyakarta: Ar-Ruzz Media.

Sugiyono. (2015). Metode Penelitian Kuantitaif Kualitatif dan R\&D. Bandung: Alfabeta.

Susanto, A. (2016). Teori Belajar \& Pembelajaran di Sekolah Dasar. Jakarta: Prenadamedia Group.

Susilana, R \& Riyana, C. (2007). Media Pembelajaran. Bandung: CV Wacana Prima.

Ulva,P.(2015). Penerapan Model Number Head Together dengan Media Flashcard dalam Peningkatan Pembelajaran Matematika Siswa Kelas IV SD Negeri 3 Dorowati Tahun Ajaran 2014/2015(Versi Elektronik).Jurnal Pendidikan, 3 (5.1), 491-496. Diperoleh pada 7 November 2017 dari http://www.jurnal.fkip.uns.ac.id.

Undang-undang Nomor 20 Tahun 2003 tentang Sistem Pendidikan Nasional. Sekretariat Negara. Jakarta 